\title{
Suitability of Sphagnum Moss, Coir, and Douglas Fir Bark as Soilless Substrates for Container Production of Highbush Blueberry
}

\author{
Patrick H. Kingston \\ Department of Horticulture, 4017 Agriculture and Life Sciences Building, \\ Oregon State University, Corvallis, OR 97331
}

\section{Carolyn F. Scagel ${ }^{1}$ and David R. Bryla}

U.S. Department of Agriculture, Agricultural Research Service, Horticultural Crops Research Unit, 3420 NW Orchard Avenue, Corvallis, OR 97330

\section{Bernadine Strik \\ Department of Horticulture, 4017 Agriculture and Life Sciences Building, Oregon State University, Corvallis, OR 97331}

Additional index words. Vaccinium, greenhouse production, soilless media

\begin{abstract}
The purpose of the present study was to investigate the suitability of different soilless substrates for container production of highbush blueberry (Vaccinium sp.). Young plants of 'Snowchaser' blueberry were grown in 4.4-L pots filled with media containing $10 \%$ perlite and varying proportions of sphagnum moss, coconut (Cocos nucifera $\mathrm{L}$.) coir, and douglas fir [Pseudotsuga menziesii Mirb. (Franco)] bark, as well as a commercially available mix of peatmoss, perlite, and other ingredients for comparison. Total plant dry weight (DW) was similar among the treatments at 72 days after transplanting, but at 128 days, total DW was nearly twice as much in the commercial mix and in media with $\geq 60 \%$ peat or coir than in media with $\geq 60 \%$ bark. Inadequate irrigation likely played a role in poor plant growth in bark. Bark had lower porosity and water holding capacity than peat, coir, or the commercial mix and, therefore, dried quickly between irrigations. Bark also reduced plant uptake efficiency of a number of nutrients, including $\mathrm{N}, \mathrm{P}, \mathrm{K}, \mathrm{S}, \mathrm{Ca}, \mathrm{Mg}, \mathrm{Mn}$, $\mathrm{B}, \mathrm{Cu}$, and $\mathrm{Zn}$. Uptake efficiency of $\mathrm{P}, \mathrm{K}$, and $\mathrm{Mg}$ also differed between plants grown in peat and coir, which in most cases was a function of the initial concentration of nutrients in the media. Before planting, peat had the highest concentration of $\mathrm{Mg}$ and $\mathrm{Fe}$ among the media, whereas coir had the highest concentration of $P$ and $K$. Leachate $\mathrm{pH}$ was initially lowest with peat and highest with coir but was similar among each of the media treatments by the end of the study. Electrical conductivity (EC) of leachate never exceeded $0.84 \mathrm{dS} \cdot \mathrm{m}^{-1}$ in any treatment. Overall, peat and coir appear to be good substrates for container production of highbush blueberry. Bark, on the other hand, was less suitable, particularly when it exceeded $30 \%$ of the total media composition.
\end{abstract}

Worldwide production of highbush blueberry (Vaccinium sp.) has increased tremendously in recent years, from $\approx 42,000$ ha in 2005 to over 109,000 ha in 2014 (Brazelton, 2016). This rapid growth is driven by strong

Received for publication 2 Aug. 2017. Accepted for publication 13 Oct. 2017.

This project was funded by USDA Agricultural Research Service CRIS number 2072-21000-048-00D. We thank Jesse Mitchell and Suean Ott of the U.S. Department of Agriculture (USDA) for technical assistance and Jon Umble for valuable suggestions on the manuscript. Mention of trade names or commercial products in this publication is solely for the purpose of providing specific information and does not imply recommendation or endorsement by the USDA. This article is a portion of a thesis submitted by Patrick $\mathrm{H}$. Kingston for the degree of Master of Science in Horticulture at Oregon State University.

${ }^{1}$ Corresponding author. E-mail: carolyn.scagel@ars. usda.gov. for novel ways to grow the plants in regions with suboptimal soil conditions. One such method involves cultivation in containers with soilless substrate and highly controlled fertigation management systems (Voogt et al., 2014). Although nurseries have been growing blueberry in soilless substrate for many years, the concept of commercial fruit production in containers is a relatively novel idea (Fulcher et al., 2015). Substrate mixes used in nurseries frequently contain peatmoss, coir, bark, and/or perlite, but it is unclear whether these components are also suitable for longer term fruit production of blueberry.

Partially decomposed peatmoss, derived from sphagnum peat, has historically been used for production of container-grown plants. High water holding capacity, high ion exchange capacity, resistance to decomposition, and relative abundance of peat bogs in the northern hemisphere often makes peatmoss an ideal choice for use in soilless substrates (Hammond, 1975). Peatmoss is also naturally low in $\mathrm{pH}$ (3.5-4.5) and, therefore, often considered a good substrate for acid-loving plants such as highbush blueberry (Knight et al., 1998; Scagel, 2003).

Coir is the pithy and fibrous material from the husk of coconuts and is a common alternative to peat because of its high waterholding capacity and widespread geographic availability (Evans et al., 1996). Although coir has a higher pH (5.6-6.9; Evans et al., 1996) than peat, it has been shown to be suitable for container production of ericaceous plants. Scagel (2003) reported improved growth in a wide range of ericaceous species when the plants were grown in media with coir instead of peat; however, the media never contained $>20 \%$ peat or coir by volume. Berruti and Scariot (2011) substituted a peatbased medium with up to $50 \%$ coir and found improved growth of several Rhododendron sp. in the mixes with coir.

Growers also often use inexpensive, locally available organic products such as milled tree bark as a substrate for containers. In the northwestern United States, douglas fir bark is widely available as a by-product from the logging industry and is commonly used for production of nursery plants in the region (Buamscha et al., 2007). Douglas fir bark varies widely in quality and properties, depending on how it is treated (fresh, aged, or composted), but it usually has a low $\mathrm{pH}$ (3.7-4.4) considered appropriate for blueberry (Altland and Buamscha, 2008).

The purpose of the present study was to investigate the suitability of different combinations of sphagnum moss, coconut coir, and douglas fir bark for container production of highbush blueberry. These ingredients were chosen because of their low cost and widespread use in soilless cultivation. We hypothesized that blueberry would grow best in substrates with a high proportion of peat or douglas fir bark because of the lower $\mathrm{pH}$. To test the hypothesis, southern highbush blueberry (a complex hybrid based largely on Vaccinium corymbosum L. and Vaccinium darrowii Camp.) plants were grown in media mixes with different proportions of the substrates. 


\section{Materials and Methods}

Experimental setup. The study was conducted in a glasshouse located at the USDAARS Horticultural Crops Research Unit in

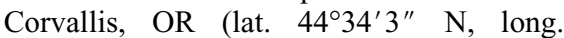
$\left.123^{\circ} 17^{\prime} 19^{\prime \prime} \mathrm{W}\right)$. Eleven media mixtures were evaluated, including 10 of which contained 10\% perlite (Horticulture expanded grade; OBC Northwest Inc., Canby, OR) by volume for drainage and $0 \%$ to $90 \%$ sphagnum moss (Sun Gro Horticulture, Hubbard, OR), coconut coir (Sun Gro Horticulture), and aged douglas fir bark (The Bark Place, Philomath, OR) (Table 1). These 10 treatments were set up as a simplex-lattice design with each media component treated as a continuous variable. This design enabled us to estimate treatment response to media mixtures not included in the study (Cornell, 2011). A commercially available potting mix (Sunshine Professional Growing Mix \#4 'LA4 P'; Sun Gro Horticulture Distribution Inc., Agawam, MA) containing peat, perlite, pumice, and other proprietary ingredients was also included in the study for comparison (Table 1). The components of this substrate are commonly used in nursery production of blueberry (J. Umble, personal communication).

On 18 Mar. 2015, 70-mL containers of 'Snowchaser' blueberry were obtained from a commercial nursery (Fall Creek Farm \& Nursery, Lowell, OR) and transplanted into 4.4-L pots $(19.7-\mathrm{cm}$ diameter $\times 16.5-\mathrm{cm}$ tall, \#2 Short; Anderson Pots, Portland, OR) filled with the media mixtures. One plant was placed in each pot, and each treatment had 10 pots, for a total of 110 plants in the experiment. Treatments were arranged in a randomized complete block design with two pots per treatment in each of five blocks. The pots were located on two adjacent greenhouse benches and spaced $0.1 \mathrm{~m}$ apart on each bench.

Each bench was illuminated from 0700 to 2100 HR using two 1000-W high-pressure sodium lamps. A thermostat was set to cool the glasshouse when temperature was $>27^{\circ} \mathrm{C}$ and to heat it when temperature was $<15^{\circ} \mathrm{C}$. Air temperature, relative humidity, and photosynthetically active radiation $(P A R)$ were measured every $15 \mathrm{~min}$ at the top of the canopy using a data logger (model LI-1400; LI-COR Biosciences, Lincoln, NE) connected to a combination temperature and humidity probe (model Humitter 50 YC; Vaisala Inc., Woburn, MA) and a pyranometer (model LI-190; LI-COR Biosciences). The data logger was installed on 22 Apr. 2015 but malfunctioned between 29 May and 26 June. Mean daily air temperature in the glasshouse ranged from 14 to $38{ }^{\circ} \mathrm{C}$ and averaged $22{ }^{\circ} \mathrm{C}$ from 22 Apr. to 29 May and $26{ }^{\circ} \mathrm{C}$ from 26 June to 24 July. Relative humidity and $P A R$ averaged $51 \%$ and 20.8 $\mathrm{mol} \cdot \mathrm{m}^{-2} \cdot \mathrm{d}^{-1}$, respectively.

The plants were irrigated as needed from 18 Mar. to 5 Apr. using a $2 \mathrm{~L} \cdot \mathrm{h}^{-1}$ drip emitter in each pot (model DPC02-MA-AL-Blue; Toro Company, El Cajon, CA). From 6 Apr. onward, plants were fertigated daily through the drip system with a modified Hoagland's nutrient solution (Hoagland and Arnon, 1938). The solution contained $5.5 \mathrm{~mm}$ $\mathrm{N}$ from $\left(\mathrm{NH}_{4}\right)_{2} \mathrm{SO}_{4}$ and $\left(\mathrm{NH}_{4}\right)_{2} \mathrm{HPO}_{4}+$ $1.14 \mathrm{mM} \mathrm{N}$ as a chelating agent used to deliver $\mathrm{Ca}$; $0.51 \mathrm{~mm} \mathrm{P}$ from $\left(\mathrm{NH}_{4}\right)_{2} \mathrm{HPO}_{4}$; $3.07 \mathrm{~mm} \mathrm{~K}$ from $\mathrm{K}_{2} \mathrm{SO}_{4} ; 2 \mathrm{mM} \mathrm{Ca}$ from a chelated $\mathrm{Ca}$ product (ProNatural Calcium; Wilbur Ellis, Aurora, CO); $0.74 \mathrm{~mm} \mathrm{Mg}$ from $\mathrm{MgSO}_{4} * 7 \mathrm{H}_{2} \mathrm{O} ; 25 \mu \mathrm{M}$ Fe from Fe-DTPA; $25 \mu \mathrm{M} \mathrm{B}$ from $\mathrm{H}_{3} \mathrm{BO}_{3} ; 3 \mu \mathrm{M}$ Mn from $\mathrm{MnCl}_{2}$ $* 4 \mathrm{H}_{2} \mathrm{O}$; and $4 \mu \mathrm{M} \mathrm{Zn}$ from $\mathrm{ZnSO}_{4} * 7 \mathrm{H}_{2} \mathrm{O}$. Sulfuric acid was also added to reduce the $\mathrm{pH}$ of the fertigation solution to 5.2. Each plant received the same volume of nutrient solution. All pots received the same volume of solution via fertigation, and leached solution

Table 1. Irrigation drainage from different media mixes used to grow potted plants of 'Snowchaser' blueberry.

\begin{tabular}{|c|c|c|c|c|c|c|}
\hline \multirow[b]{2}{*}{ Medium $^{z}$} & \multicolumn{4}{|c|}{ Composition (\%) } & \multicolumn{2}{|c|}{ Drainage $(\%)^{\mathrm{y}}$} \\
\hline & Peatmoss & Coir & Bark & $\overline{\text { Perlite }}$ & $0-72 \mathrm{~d}$ & $73-128 \mathrm{~d}$ \\
\hline $\mathrm{S}_{30} \mathrm{C}_{30} \mathrm{~B}_{30}$ & 30 & 30 & 30 & 10 & 37 & 26 \\
\hline $\mathrm{S}_{90}$ & 90 & 0 & 0 & 10 & 40 & 30 \\
\hline $\mathrm{S}_{60} \mathrm{~B}_{30}$ & 60 & 0 & 30 & 10 & 38 & 32 \\
\hline $\mathrm{S}_{60} \mathrm{C}_{30}$ & 60 & 30 & 0 & 10 & 44 & 25 \\
\hline $\mathrm{C}_{90}$ & 0 & 90 & 0 & 10 & 37 & 33 \\
\hline $\mathrm{C}_{60} \mathrm{~B}_{30}$ & 0 & 60 & 30 & 10 & 39 & 26 \\
\hline $\mathrm{C}_{60} \mathrm{~S}_{30}$ & 30 & 60 & 0 & 10 & 36 & 25 \\
\hline $\mathrm{B}_{90}$ & 0 & 0 & 90 & 10 & 60 & 47 \\
\hline $\mathrm{B}_{60} \mathrm{C}_{30}$ & 0 & 30 & 60 & 10 & 48 & 40 \\
\hline $\mathrm{B}_{60} \mathrm{~S}_{30}$ & 30 & 0 & 60 & 10 & 45 & 38 \\
\hline Commercial mix & $55-65$ & 0 & 0 & $25-30$ & 45 & 24 \\
\hline
\end{tabular}

${ }^{\mathrm{z}}$ Letters represent the component(s) of the medium ( $\mathrm{S}=$ sphagnum moss, $\mathrm{C}=$ coconut coir, $\mathrm{B}=$ douglas fir bark) and the numbers represent the percent of each component (e.g., $\mathrm{S}_{30} \mathrm{C}_{30} \mathrm{~B}_{30}$ is $30 \%$ peatmoss, $30 \%$ coir, and $30 \%$ bark). Each non-commercial medium also contained $10 \%$ perlite. Remainder of commercial mix was pumice and proprietary ingredients ( $5 \%$ to $20 \%)$.

${ }^{\mathrm{y}}$ Percentage of added solution ( $\mathrm{mL}$ fertilizer per pot $+\mathrm{mL}$ water per pot) that drained from the pots between 0 and $72 \mathrm{~d}$ and 73 and $128 \mathrm{~d}$ after transplanting. Drainage was not included from 26 to $33 \mathrm{~d}$ after transplanting due to a malfunction in the irrigation system $(2 \mathrm{~L}$ of water was applied to each pot over the 7-d period).

Table 2. Initial physical characteristics of different media mixes used to grow potted plants of 'Snowchaser' blueberry.

\begin{tabular}{|c|c|c|c|c|c|c|}
\hline \multirow[b]{2}{*}{ Medium $^{z}$} & \multirow{2}{*}{$\begin{array}{c}\text { Bulk } \\
\text { density } \\
\left(\mathrm{g} \cdot \mathrm{cm}^{-3}\right)\end{array}$} & \multirow[b]{2}{*}{ Porosity (\%) } & \multicolumn{3}{|c|}{ Particle size $(\%)^{y}$} & \multirow{2}{*}{$\begin{array}{l}\text { Cation exchange } \\
\text { capacity } \\
\text { (meq/100 g soil) }\end{array}$} \\
\hline & & & Coarse & Medium & Fine & \\
\hline $\mathrm{S}_{30} \mathrm{C}_{30} \mathrm{~B}_{30}$ & 0.16 & 82 & 52.6 & 22.8 & 24.6 & 21 \\
\hline $\mathrm{S}_{90}$ & 0.08 & 86 & 58.1 & 20.8 & 21.1 & 27 \\
\hline $\mathrm{S}_{60} \mathrm{~B}_{30}$ & 0.14 & 84 & 62.2 & 20.0 & 17.8 & 28 \\
\hline $\mathrm{S}_{60} \mathrm{C}_{30}$ & 0.08 & 86 & 47.1 & 24.5 & 28.4 & 22 \\
\hline $\mathrm{C}_{90}$ & 0.08 & 85 & 19.9 & 31.6 & 48.5 & 15 \\
\hline $\mathrm{C}_{60} \mathrm{~B}_{30}$ & 0.18 & 80 & 44.9 & 25.5 & 29.6 & 18 \\
\hline $\mathrm{C}_{60} \mathrm{~S}_{30}$ & 0.08 & 86 & 34.9 & 25.8 & 39.3 & 19 \\
\hline $\mathrm{B}_{90}$ & 0.31 & 76 & 59.7 & 25.9 & 14.3 & 24 \\
\hline $\mathrm{B}_{60} \mathrm{C}_{30}$ & 0.25 & 77 & 51.3 & 26.9 & 21.8 & 23 \\
\hline $\mathrm{B}_{60} \mathrm{~S}_{30}$ & 0.24 & 79 & 58.7 & 24.9 & 16.4 & 23 \\
\hline Commercial mix & 0.14 & 82 & 47.6 & 26.2 & 26.3 & 28 \\
\hline \multicolumn{7}{|c|}{ Media component correlations ${ }^{\mathrm{x}}$} \\
\hline Peatmoss & NS & 0.6801 & NS & -0.8581 & NS & 0.6068 \\
\hline Coir & NS & NS & -0.9535 & 0.6594 & 0.9535 & -0.9340 \\
\hline Bark & 0.9837 & -0.9535 & NS & NS & -0.7119 & NS \\
\hline \multicolumn{7}{|c|}{ Dry weight correlations ${ }^{x}$} \\
\hline $72 \mathrm{~d}$ & -0.6889 & 0.6150 & NS & NS & NS & NS \\
\hline $128 \mathrm{~d}$ & -0.6855 & 0.6273 & 0.7000 & NS & 0.7636 & NS \\
\hline
\end{tabular}

${ }^{\mathrm{z}}$ Letters represent the component(s) of the medium $(\mathrm{S}=$ sphagnum moss, $\mathrm{C}=$ coconut coir, $\mathrm{B}=$ douglas fir bark) and the numbers represent the percent of each component (e.g., $\mathrm{S}_{30} \mathrm{C}_{30} \mathrm{~B}_{30}$ is $30 \%$ peatmoss, $30 \%$ coir, and $30 \%$ bark). Each non-commercial medium also contained $10 \%$ perlite (see Table 1).

${ }^{\mathrm{y}}$ Coarse $>2.4 \mathrm{~mm}$; medium $=0.85-2.4 \mathrm{~mm}$; fine $<0.85 \mathrm{~mm}$.

${ }^{\mathrm{x}}$ Spearman $R$ values $(P \leq 0.05)$ for relationships between the proportion of peat, coir, or bark in the media and the physical characteristics of the media, and between the total plant dry weight at either 72 or $128 \mathrm{~d}$ after transplanting and the physical characteristics of the media. No significant relationship denoted by Ns. The commercial mix was not included in the dry weight analyses. 
by $72 \mathrm{~d}$ and $9.7 \mathrm{~L}$ by $128 \mathrm{~d}$. The combined total of irrigation and fertigation provided to plants was 9.2-10.7 L at $72 \mathrm{~d}$ and $17.1-24.9 \mathrm{~L}$ at $128 \mathrm{~d}$.

At $\approx 6$ weeks after transplanting, plants in $90 \%$ bark had red-tinged leaves, a common symptom of $\mathrm{N}$ deficiency in blueberry (Hart et al., 2006b). Following this discovery and coupled with data on differences in percent drainage among treatments (Table 1), the fertigation schedule was changed from every other day to every day to reduce large discrepancies in drainage. This change in fertigation frequency kept more fertilizer solution in the root-zone and eliminated any $\mathrm{N}$ deficiency symptoms by $78 \mathrm{~d}$ after transplanting.

Measurements. Physical and chemical properties of the media were analyzed by a commercial laboratory (Soil Control Laboratory, Watsonville, CA) to compare initial differences in media properties. Bulk density and porosity of the media were determined using the method described by Niedziela and Nelson (1992). Particle-size distribution was determined using displacement by shaking $100 \mathrm{~g}$ of dry media through stacked sieves with openings decreasing in size $(25,16,9.5$, $6.3,4.0,2.0$, and $0.85 \mathrm{~mm}$ ) for $5 \mathrm{~min}$ and obtaining the percent of material $(\mathrm{w} / \mathrm{w} \%)$ in each sieve. Media cation exchange capacity (CEC) was determined using sodium acetate solution. Percent $\mathrm{C}$ and $\mathrm{N}$ were determined using a combustion analyzer (TruSpec $\mathrm{CN}$; Leco Corp., St. Joseph, MI), concentration of $\mathrm{NH}_{4}-\mathrm{N}$ was determined with a selective ion electrode procedure (Sims et al., 1995), concentrations of $\mathrm{Cl}$ and $\mathrm{S}_{-} \mathrm{SO}_{4}$ were determined by ion chromatography, and $\mathrm{EC}$ and $\mathrm{pH}$ were measured in a 1:5 substrate: deionized water extract (Robbins and Wiegand, 1990). Nutrient composition of media samples was determined by inductively coupled plasma (ICP) spectrophotometry after extraction using Mehlich 1 for $\mathrm{P}, \mathrm{K}, \mathrm{Ca}, \mathrm{Mg}$, and $\mathrm{Na}$, DPTA for $\mathrm{Cu}, \mathrm{Zn}, \mathrm{Fe}$, and $\mathrm{Mn}$, and hot water for B (Gavlak et al., 2003).

To monitor $\mathrm{pH}$ and $\mathrm{EC}$ changes in media over time, leachate was collected from the pots every 2 weeks from three blocks per treatment using a modified pour-through method (Wright, 1986) and was analyzed for $\mathrm{pH}$ and $\mathrm{EC}$ using a $\mathrm{pH} / \mathrm{ion} /$ conductivity meter (model SevenGo Duo pro with an InLab Expert Pro-ISM-IP67 probe for $\mathrm{pH}$ and an InLab 738 ISM conductivity probe for EC; Mettler-Toledo, Columbus, OH). The procedure of Wright (1986) was modified by irrigating all pots simultaneously by using drip emitters with $67 \mathrm{~mL}$ of irrigation water per container at $\approx 1 \mathrm{~h}$ after a fertigation event. This modification improved the uniformity of leachate volume collection $(\approx 50 \mathrm{~mL} /$ pot $)$ by reducing the amount of time required to manually add deionized water. The leachate was then stored at $3{ }^{\circ} \mathrm{C}$ until analysis and later measured at $25{ }^{\circ} \mathrm{C}$ in a water bath. Leachate data were only collected from a subset of treatments with ion-selective membrane probes (i.e., $\mathrm{S}_{30} \mathrm{C}_{30} \mathrm{~B}_{30}, \mathrm{~S}_{90}, \mathrm{C}_{90}$, and $\mathrm{B}_{90}$; Table 1; WesternAg Innovations, Saskatoon, Saskatchewan, Canada). In these treatments, two anion and two cation probes were inserted vertically into the medium at $2.5 \mathrm{~cm}$ from the edge of each pot. The probes were buried every 2 weeks for a period of $7 \mathrm{~d}$ (removed on the same day as the pourthroughs) and then sent to the manufacturer for analysis of $\mathrm{NO}_{3}{ }^{-}, \mathrm{NH}_{4}{ }^{+}, \mathrm{P}, \mathrm{K}, \mathrm{Ca}, \mathrm{Mg}, \mathrm{S}$, $\mathrm{Fe}, \mathrm{Mn}, \mathrm{Cu}, \mathrm{Zn}, \mathrm{B}, \mathrm{Al}, \mathrm{Pb}$, and $\mathrm{Cd}$ absorbed on the membranes.

Plants were destructively harvested at 0 , 72 , and $128 \mathrm{~d}$ after transplanting. At each harvest, the shoots were cut off at the surface of the media, rinsed with distilled water, separated into stems and leaves, and oven-dried at
$60{ }^{\circ} \mathrm{C}$ until no change in mass was observed over a 24 -h period. The pots were then placed in a cooler set at $3{ }^{\circ} \mathrm{C}$, and roots were later removed from the media by washing and oven-dried at $60{ }^{\circ} \mathrm{C}$. Each plant component was then weighed and ground to pass through a 1-mm screen. The ground samples were analyzed for $\mathrm{N}$ using a combustion analyzer (TruSpec CN; Leco Corp.; Scagel et al., 2007) and for P, K, S, Ca, Mg, Fe, B, Cu, Mn, Zn, and $\mathrm{Na}$ by ICP-optical emission spectrometry (Perkin Elmer Optima 3000DV; Perkin Elmer, Wellesley, MA) after microwave digestion with $70 \%(\mathrm{v} / \mathrm{v})$ nitric acid in a microwave (Gavlak et al., 2003; Jones and Case, 1990). Reference standard apple (M. domestica L.) leaves (no. 151, National Institute of Standards and Technology) were included in each set of samples to ensure accuracy of instrument and digestion procedures.

Whole plant DW was obtained by adding the dry mass of all plant tissues for a given experimental unit. Nutrient content of each plant tissue was calculated by multiplying the DW of each tissue by its nutrient concentration. For each nutrient, whole plant concentration was calculated by adding the nutrient content in each tissue and dividing the sum by whole plant DW. Nutrient uptake efficiency (NUE) was calculated by dividing net uptake of each nutrient [i.e., difference in the total content of the nutrient at transplanting (day 0 ) and at $128 \mathrm{~d}$ after transplanting] by the quantity of that nutrient available from the medium (obtained from chemical analysis of each medium) and added during fertigation.

Data analysis. Data were analyzed using RStudio (version 0.99.903; RStudio INC., Boston, MA) running $\mathrm{R}$ (version 3.3.1; $\mathrm{R}$ Core Team, 2016). For DW, NUE, and nutrient concentration data, linear polynomial models were fit to account for the

Table 3. Initial chemical characteristics of different media mixes used to grow potted plants of 'Snowchaser' blueberry.

\begin{tabular}{|c|c|c|c|c|c|c|c|c|c|c|c|c|c|c|c|c|}
\hline \multirow[b]{2}{*}{ Medium $^{z}$} & \multirow[b]{2}{*}{$\mathrm{pH}$} & \multirow{2}{*}{$\begin{array}{c}\text { EC } \\
\left(\mathrm{dS} \cdot \mathrm{m}^{-1}\right) \\
\end{array}$} & \multirow{2}{*}{$\begin{array}{c}\text { Total } \\
\mathrm{N}(\%) \\
\end{array}$} & \multirow{2}{*}{$\begin{array}{l}\mathrm{C}: \mathrm{N} \\
\text { ratio }\end{array}$} & \multicolumn{12}{|c|}{ Nutrient concn (ppm) } \\
\hline & & & & & $\mathrm{NH}_{4}-\mathrm{N}$ & $\mathrm{P}$ & $\mathrm{K}$ & $\mathrm{Ca}$ & $\mathrm{Mg}$ & $\mathrm{SO}_{4}-\mathrm{S}$ & $\mathrm{Fe}$ & $\mathrm{Mn}$ & B & $\mathrm{Cu}$ & $\mathrm{Zn}$ & $\mathrm{Na}$ \\
\hline $\mathrm{S}_{90}$ & 4.4 & 0.31 & 0.83 & 44 & 3.1 & 7 & 128 & 8,017 & 1,304 & 68 & 411 & 21 & 1.4 & 1.0 & 7.0 & 85 \\
\hline $\mathrm{C}_{90}$ & 6.6 & 1.20 & 0.50 & 70 & 3.4 & 493 & 8,689 & 3,124 & 155 & 183 & 40 & 29 & 4.8 & 1.5 & 9.1 & 1,260 \\
\hline $\mathrm{C}_{60} \mathrm{~B}_{30}$ & 5.9 & 0.74 & 0.39 & 80 & 2.5 & 89 & 3,290 & 3,471 & 1,039 & 86 & 436 & 47 & 1.9 & 3.0 & 5.0 & 661 \\
\hline $\mathrm{C}_{60} \mathrm{~S}_{30}$ & 5.8 & 0.91 & 0.60 & 55 & 2.2 & 280 & 6,185 & 5,380 & 1,533 & 140 & 137 & 29 & 4.0 & 1.5 & 7.9 & 912 \\
\hline $\mathrm{B}_{60} \mathrm{~S}_{30}$ & 5.4 & 0.22 & 0.34 & 78 & 2.0 & 13 & 602 & 3,701 & 797 & 31 & 1,056 & 77 & 1.0 & 5.9 & 6.6 & 345 \\
\hline $\begin{array}{l}\text { Commercial } \\
\text { mix }\end{array}$ & 5.7 & 4.95 & 0.59 & 31 & 3.4 & 590 & 1,386 & 5,539 & 2,489 & 2,353 & 134 & 23 & 1.3 & 1.2 & 10.3 & 152 \\
\hline \multicolumn{17}{|c|}{ Media component correlations ${ }^{y}$} \\
\hline Peatmoss & -0.9202 & NS & 0.7437 & -0.8671 & NS & NS & NS & 0.7437 & NS & NS & NS & NS & NS & NS & NS & NS \\
\hline Coir & 0.7523 & 0.9534 & NS & NS & NS & 0.8454 & 0.9535 & NS & NS & 0.8327 & -0.7119 & NS & 0.8917 & NS & NS & 0.9534 \\
\hline Bark & NS & NS & -0.9090 & 0.8193 & -0.8129 & NS & NS & NS & NS & -0.8772 & 0.7373 & 0.6376 & -0.7922 & 0.7396 & -0.7100 & NS \\
\hline
\end{tabular}

${ }^{\mathrm{z}}$ Letters represent the component( $(\mathrm{s})$ of the medium $(\mathrm{S}=$ sphagnum moss, $\mathrm{C}=$ coconut coir, $\mathrm{B}=$ douglas fir bark) and the numbers represent the percent of each component (e.g., $\mathrm{S}_{30} \mathrm{C}_{30} \mathrm{~B}_{30}$ is $30 \%$ peatmoss, $30 \%$ coir, and $30 \%$ bark). Each non-commercial medium also contained $10 \%$ perlite (see Table 1 ).

${ }^{\mathrm{y}}$ Spearman $R$ values $(P \leq 0.05)$ for relationships between the proportion of peat, coir, or bark in the media and the physical characteristics of the media, and between the total plant dry weight at either 72 or $128 \mathrm{~d}$ after transplanting and the physical characteristics of the media. No significant relationship denoted by NS. The commercial mix was not included in the dry weight analyses.

$\mathrm{EC}=$ electrical conductivity. 


\section{A. Biomass (g dw/plant) at $72 \mathrm{~d}$}

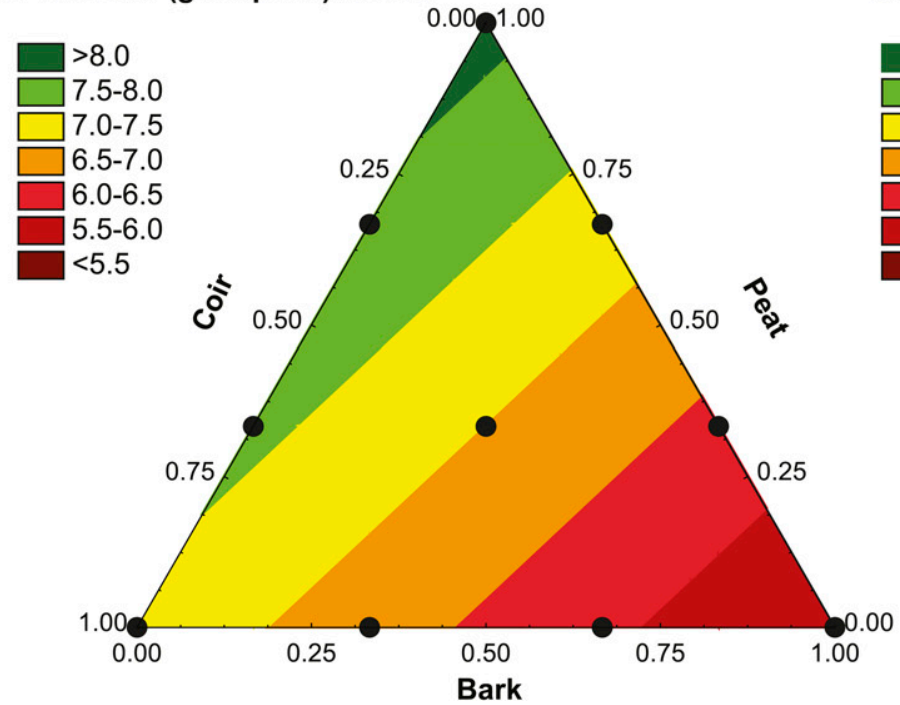

B. Biomass (g dw/plant) at $128 \mathrm{~d}$

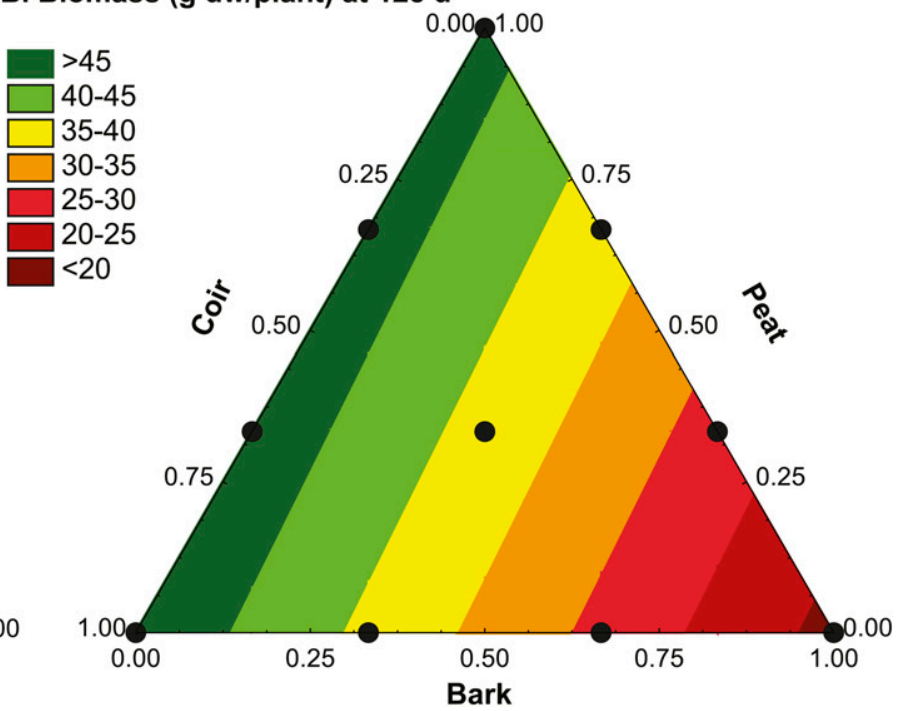

Fig. 1. Total dry weight (DW) (g/plant) of 'Snowchaser' blueberry plants at (A) $72 \mathrm{~d}$ and (B) $128 \mathrm{~d}$ after transplanting. Each side of the triangle represents the proportion of the substrate contained in the media. Black circles represent the proportions used in experiment, and contour lines represent the linear response of total plant DW to various proportions of peat, coir, and bark in the media mix $(P \leq 0.05)$.

Table 4. Dry weight (DW) of 'Snowchaser' blueberry plants grown in pots containing different media mixes.

\begin{tabular}{|c|c|c|c|c|c|c|c|c|}
\hline \multirow[b]{3}{*}{ Medium $^{z}$} & \multicolumn{8}{|c|}{ Dry wt $(g / \text { plant })^{y}$} \\
\hline & \multicolumn{4}{|c|}{$72 \mathrm{~d}$ after transplanting } & \multicolumn{4}{|c|}{$128 \mathrm{~d}$ after transplanting } \\
\hline & Total & Roots & Stems & Leaves & Total & Roots & Stems & $\overline{\text { Leaves }}$ \\
\hline$\overline{\mathrm{S}_{30} \mathrm{C}_{30} \mathrm{~B}_{30}}$ & 6.6 & 2.1 & 1.4 & 3.1 & 42.8 & 9.4 & 12.3 & 21.1 \\
\hline $\mathrm{S}_{90}$ & 8.0 & 1.9 & 1.4 & 4.6 & 45.3 & 10.4 & 13.4 & 21.5 \\
\hline $\mathrm{S}_{60} \mathrm{~B}_{30}$ & 6.5 & 1.8 & 1.3 & 3.3 & 39.9 & 9.5 & 11.4 & $19.0^{*}$ \\
\hline $\mathrm{S}_{60} \mathrm{C}_{30}$ & 8.2 & 2.1 & 1.8 & 4.3 & 48.0 & 9.4 & 14.1 & 24.5 \\
\hline $\mathrm{C}_{90}$ & 6.2 & 1.9 & 1.3 & 3.0 & 43.1 & 10.5 & 11.5 & 21.1 \\
\hline $\mathrm{C}_{60} \mathrm{~B}_{30}$ & 8.1 & 2.1 & 1.6 & 4.5 & 47.7 & 11.2 & 14.1 & 22.4 \\
\hline $\mathrm{C}_{60} \mathrm{~S}_{30}$ & 8.4 & 2.2 & 1.5 & 4.6 & 46.3 & 13.2 & 12.7 & 20.5 \\
\hline $\mathrm{B}_{90}$ & 5.3 & 1.8 & 1.3 & 2.2 & $15.3 *$ & 3.8 & $4.7 *$ & $6.8^{*}$ \\
\hline $\mathrm{B}_{60} \mathrm{C}_{30}$ & 5.3 & 1.6 & 1.3 & 2.4 & $28.3^{*}$ & 8.2 & 7.7 & $12.4^{*}$ \\
\hline $\mathrm{B}_{60} \mathrm{~S}_{30}$ & 7.3 & 2.1 & 1.4 & 3.7 & $24.9 *$ & 6.5 & $7.5^{*}$ & 11.0 \\
\hline Commercial mix & 7.6 & 2.1 & 1.5 & 4.0 & 45.7 & 9.7 & 11.4 & 24.6 \\
\hline \multicolumn{9}{|c|}{ Mixture model results ${ }^{\mathrm{y}}$} \\
\hline$P$ value & 0.0473 & 0.6425 & 0.4375 & 0.0105 & $<0.0001$ & 0.0005 & $<0.0001$ & $<0.0001$ \\
\hline$r^{2}$ adj & 0.1216 & 0.0187 & 0.0573 & 0.1762 & 0.6392 & 0.2800 & 0.5743 & 0.6566 \\
\hline \multicolumn{9}{|l|}{ Coefficients $(\beta)$} \\
\hline Peat & $8.1 \mathrm{a}$ & $2.0 \mathrm{a}$ & $1.5 \mathrm{a}$ & $4.5 \mathrm{a}$ & $46.9 \mathrm{a}$ & $10.3 \mathrm{a}$ & $13.8 \mathrm{a}$ & $22.7 \mathrm{a}$ \\
\hline Coir & $7.4 \mathrm{ab}$ & $2.0 \mathrm{a}$ & $1.5 \mathrm{a}$ & $3.8 \mathrm{a}$ & $49.2 \mathrm{a}$ & $12.2 \mathrm{a}$ & $13.5 \mathrm{a}$ & $23.4 \mathrm{a}$ \\
\hline Bark & $5.5 \mathrm{~b}$ & $1.8 \mathrm{a}$ & $1.3 \mathrm{a}$ & $2.3 \mathrm{~b}$ & $18.3 \mathrm{~b}$ & $5.0 \mathrm{~b}$ & $5.5 \mathrm{~b}$ & $7.9 \mathrm{~b}$ \\
\hline
\end{tabular}

${ }^{\mathrm{z}}$ Letters represent the component(s) of the medium $(\mathrm{S}=$ sphagnum moss, $\mathrm{C}=$ coconut coir, $\mathrm{B}=$ douglas fir bark) and the numbers represent the percent of each component (e.g., $\mathrm{S}_{30} \mathrm{C}_{30} \mathrm{~B}_{30}$ is $30 \%$ peatmoss, $30 \%$ coir, and 30\% bark). Each non-commercial medium also contained 10\% perlite (see Table 1 ).

${ }^{\mathrm{y}}$ Mixture model $P$ values, adjusted correlation coefficients $\left(r^{2}\right.$ adj $)$, and coefficients $(\beta)$ for each model component. Coefficients followed by the same lower-case letter within a column are not significantly different based on Tukey's honestly significant difference test $(P \leq 0.05)$. * Significantly different from the commercial mix at a 95\% level using Dunnett-Hsu adjustment.

simplex-lattice design and estimate the effect of each ingredient proportion using the ' $\mathrm{lm}$ ' function (Scheffé, 1958); the commercial mix treatment was excluded from the analysis. One plant died in a pot filled with a 2:1 mix of peat and bark before the second harvest date (due to an accidental loss of irrigation) and, therefore, was also removed from the analysis. Spearman rank order correlation $(R)$ was used to estimate correlative relationships of physical and chemical properties of the media mixtures with individual media proportions and plant DW at 72 and $128 \mathrm{~d}$ after transplanting using Statistical analytical software system (Version 13; Dell, Inc., Tulsa, OK). Comparisons between all treatments and the commercial control were done using the PROC MIXED procedure in SAS (v. 9.4; SAS Institute Inc., Cary, NC) and the Duncan-Hsu adjustment for multiple group comparisons. Data from pour-through leachate and ion-selective membrane probes were analyzed using a linear mixed model (package "nlme"), and all pairwise comparisons were made using Tukey's honestly significant difference test at the 0.05 level in the "lsmeans" package (Lenth, 2016; Pinheiro et al., 2016).

\section{Results}

Initial media composition. Initial physical and chemical characteristics differed among the 11 media (Tables 2 and 3). Adding more peat increased porosity, $\mathrm{CEC}$, total $\mathrm{N}$, and $\mathrm{Ca}$ concentration in the medium and reduced the percentage of medium-sized particles, $\mathrm{pH}$, and the $\mathrm{C}: \mathrm{N}$ ratio. Adding more coir, on the other hand, increased the percentage of medium- and fine-sized particles, $\mathrm{pH}, \mathrm{EC}$, and $\mathrm{P}$, $\mathrm{K}, \mathrm{SO}_{4}-\mathrm{S}, \mathrm{B}, \mathrm{Cl}$, and $\mathrm{Na}$ concentration in the medium and reduced the percentage of coarse-sized particles, CEC, and Fe concentration in the medium $(\mathrm{Cl}$ concentration data not shown). Finally, more bark increased bulk density, the $\mathrm{C}: \mathrm{N}$, and $\mathrm{Fe}$ and $\mathrm{Cu}$ concentration in the medium and reduced porosity, the percentage of fine-sized particles, total $\mathrm{C}$ and $\mathrm{N}$, and $\mathrm{NH}_{4}-\mathrm{N}, \mathrm{SO}_{4}-\mathrm{S}, \mathrm{B}, \mathrm{Mn}$, $\mathrm{Zn}$, and $\mathrm{Cl}$ concentration in the medium (total $\mathrm{C}$ and $\mathrm{Cl}$ concentration data not shown). More bark also reduced water holding capacity and, therefore, resulted in more drainage (Table 1).

Plant DW. At 72 and $128 \mathrm{~d}$ after transplanting, total plant DW increased with greater proportions of peat or coir and decreased with greater proportions of bark in the medium (Fig. 1). Based on estimates from the simplex-lattice design, media with $>30 \%$ bark resulted in less plant DW than those with $\geq 60 \%$ coir or peat. The latter treatments resulted in the same amount of DW in each plant part as the commercial mix (Table 4). A high percentage of bark in the medium reduced leaf DW at $72 \mathrm{~d}$ after transplanting and decreased DW of each organ at $128 \mathrm{~d}$. Total plant DW was positively correlated to a number of media characteristics at 72 or $128 \mathrm{~d}$, including porosity, the percentage of coarseand fine-sized particles, EC, total $\mathrm{N}$, and concentration of $\mathrm{NH}_{4}-\mathrm{N}, \mathrm{SO}_{4}-\mathrm{S}, \mathrm{Mg}$, and $\mathrm{B}$, and was negatively correlated to bulk density, 
$\mathrm{CN}$ ratio, and concentration of $\mathrm{Fe}$ (Tables 2 and 3). Total plant DW was also correlated to the concentration of $\mathrm{Cu}$ in the media, but in this case, it had a positive relationship at $72 \mathrm{~d}$ and a negative relationship at $128 \mathrm{~d}$.

Whole-plant nutrient concentration. Adding more bark to the media resulted in higher concentrations of Fe, $\mathrm{Mn}$, and $\mathrm{B}$ in the plants than adding more peat or coir, whereas more peat resulted in a higher $\mathrm{N}$ concentration and lower $\mathrm{K}$ and $\mathrm{Cu}$ concentrations, and more bark resulted in higher $\mathrm{Fe}$ and $\mathrm{Mn}$ concentrations than the commercial mix (Table 5). The media treatments had no effect on concentration of $\mathrm{P}, \mathrm{Ca}, \mathrm{Mg}, \mathrm{S}$, or $\mathrm{Zn}$ in the plants. At $128 \mathrm{~d}$ after transplanting, concentrations of these nutrients ranged from 0.07 to $0.14 \mathrm{mg} \cdot \mathrm{g}^{-1} \mathrm{P}, 0.27$ to $0.95 \mathrm{mg} \cdot \mathrm{g}^{-1} \mathrm{Ca}, 0.12$ to $0.29 \mathrm{mg} \cdot \mathrm{g}^{-1} \mathrm{Mg}, 0.09$ to $0.29 \mathrm{mg} \cdot \mathrm{g}^{-1} \mathrm{~S}$, and 6 to $22 \mathrm{mg} \cdot \mathrm{kg}^{-1} \mathrm{Zn}$.

NUE. Nutrient uptake efficiency was consistently higher in media with more peat or coir than in those with more bark (Table 6). Adding more peat also improved $\mathrm{P}$ and $\mathrm{K}$ uptake efficiency relative to more coir in the media, whereas more coir improved $\mathrm{Mg}$ uptake efficiency relative to more peat. With few exceptions, plant uptake of many nutrients, including $\mathrm{N}, \mathrm{P}, \mathrm{S}, \mathrm{Ca}, \mathrm{Mg}, \mathrm{Mn}$, and $\mathrm{Zn}$, was less efficient in the commercial mix than in media containing $\geq 60 \%$ peat or coir, whereas $\mathrm{K}, \mathrm{Ca}, \mathrm{B}, \mathrm{Cu}$, and $\mathrm{Zn}$ uptake was more efficient in the commercial mix than in media containing $\geq 60 \%$ bark.

Leachate $\mathrm{pH}$ and EC. Initially, leachate $\mathrm{pH}$ was highest in medium with $90 \%$ coir and lowest in medium with $90 \%$ peat (Fig. 2). However, differences in $\mathrm{pH}$ diminished during the experiment, and by $78 \mathrm{~d}$ after transplanting, values were similar among the measured treatments. Over time, leachate $\mathrm{pH}$ increased from 4.3 to 5.5 with $90 \%$ peat, from 5.9 to 6.9 with $90 \%$ bark, and from 5.5 to 6.5 in the $\mathrm{S}_{30} \mathrm{C}_{30} \mathrm{~B}_{30}$ mix. The $\mathrm{pH}$ of leachate in the treatment with $90 \%$ coir changed little during the experiment.

Leachate EC was greater in $90 \%$ bark $\left(0.84 \mathrm{dS} \cdot \mathrm{m}^{-1}\right)$ than in $90 \%$ peat or coir $(0.34$ and $0.46 \mathrm{dS} \cdot \mathrm{m}^{-1}$, respectively) at $35 \mathrm{~d}$ after transplanting and was greater in $90 \%$ coir $\left(0.38 \mathrm{dS} \cdot \mathrm{m}^{-1}\right)$ than in $90 \%$ peat or bark $(0.12$ and $0.16 \mathrm{dS} \cdot \mathrm{m}^{-1}$, respectively) at $119 \mathrm{~d}$ after transplanting. Mean leachate EC varied over time but never exceeded $0.87 \mathrm{dS} \cdot \mathrm{m}^{-1}$ in any treatment during the experiment (data not shown). An EC of $<2 \mathrm{dS} \cdot \mathrm{m}^{-1}$ is considered safe for highbush blueberry (Machado et al., 2014).

Nutrient availability. Availability of $\mathrm{NH}_{4}-\mathrm{N}$ was similar among media with $90 \%$ peat, $90 \%$ coir, $90 \%$ bark, or an equal mix of peat, coir, and bark (Fig. 3A). However, 90\% coir had more available $\mathrm{NO}_{3}-\mathrm{N}, \mathrm{P}$, and $\mathrm{K}$ over time than the other three media treatments (Fig. 3B-D). Furthermore, 90\% peat had more $\mathrm{P}$ than $90 \%$ bark or the peat-coirbark mix and more available $\mathrm{Ca}$ than $90 \%$ coir (Fig. 3C and E). The mix containing 30\% of each ingredient, on the other hand, had more $\mathrm{K}$ than $90 \%$ peat or bark (Fig. 3D), whereas $90 \%$ bark and the mix had more $\mathrm{Fe}$ and $\mathrm{Mn}$ than $90 \%$ peat or coir (Fig. 3E and $\mathrm{G})$. Availability of the other measured elements, including $\mathrm{S}, \mathrm{B}, \mathrm{Cu}, \mathrm{Zn}, \mathrm{Al}, \mathrm{Pb}$, and $\mathrm{Cd}$, increased over time and were similar among the treatments (data not shown).

\section{Discussion}

Media containing a high proportion of douglas fir bark resulted in less plant growth

Table 5. Nutrient concentrations in 'Snowchaser' blueberry plants grown in pots containing different media mixes. ${ }^{z}$

\begin{tabular}{|c|c|c|c|c|c|c|}
\hline \multirow[b]{2}{*}{ Medium $^{y}$} & \multicolumn{2}{|c|}{ Macronutrients $\left(\mathrm{mg} \cdot \mathrm{g}^{-1}\right)$} & \multicolumn{4}{|c|}{ Micronutrients $\left(\mu \mathrm{g} \cdot \mathrm{g}^{-1}\right)$} \\
\hline & $\mathrm{N}$ & $\mathrm{K}$ & $\mathrm{Fe}$ & $\mathrm{Mn}$ & B & $\mathrm{Cu}$ \\
\hline$\overline{\mathrm{S}_{30} \mathrm{C}_{30} \mathrm{~B}_{30}}$ & 9.2 & 5.7 & 116 & $480^{*}$ & 28 & 14 \\
\hline $\mathrm{S}_{90}$ & 10.7 & 4.9 & 74 & 134 & 27 & 11 \\
\hline $\mathrm{S}_{60} \mathrm{~B}_{30}$ & 9.8 & 5.3 & 153 & $542 *$ & 28 & 13 \\
\hline $\mathrm{S}_{60} \mathrm{C}_{30}$ & 9.4 & 5.1 & 86 & 130 & 25 & 10 \\
\hline $\mathrm{C}_{90}$ & 9.2 & 6.5 & 84 & 114 & 28 & 15 \\
\hline $\mathrm{C}_{60} \mathrm{~B}_{30}$ & 8.9 & 6.4 & 197 & $385^{*}$ & 31 & 15 \\
\hline $\mathrm{C}_{60} \mathrm{~S}_{30}$ & 8.8 & 5.4 & 69 & 135 & 23 & 13 \\
\hline $\mathrm{B}_{90}$ & 9.5 & 6.2 & $267 *$ & $589^{*}$ & 32 & 12 \\
\hline $\mathrm{B}_{60} \mathrm{C}_{30}$ & 9.1 & 5.7 & $341 *$ & $495^{*}$ & 30 & 17 \\
\hline $\mathrm{B}_{60} \mathrm{~S}_{30}$ & 9.8 & 5.6 & $218^{*}$ & $552 *$ & 28 & 12 \\
\hline Commercial mix & 9.7 & 5.5 & 69 & 87 & 26 & 13 \\
\hline \multicolumn{7}{|c|}{ Mixture model results ${ }^{\mathrm{x}}$} \\
\hline$P$ value & 0.0214 & 0.0190 & $<0.0001$ & $<0.0001$ & 0.0037 & 0.0861 \\
\hline$r_{\text {adj }}^{2}$ & 0.1539 & 0.1583 & 0.3337 & 0.9209 & 0.2163 & 0.1011 \\
\hline \multicolumn{7}{|l|}{ Coefficients $(\beta)$} \\
\hline Peat & $10.2 \mathrm{a}$ & $4.8 \mathrm{~b}$ & $75 \mathrm{~b}$ & $138 \mathrm{~b}$ & $25 \mathrm{~b}$ & $10 \mathrm{~b}$ \\
\hline Coir & $8.7 \mathrm{~b}$ & $6.5 \mathrm{a}$ & $94 \mathrm{~b}$ & $118 \mathrm{~b}$ & $27 \mathrm{~b}$ & $15 \mathrm{a}$ \\
\hline Bark & $9.4 \mathrm{ab}$ & $6.0 \mathrm{a}$ & $373 \mathrm{a}$ & $518 \mathrm{a}$ & $32 \mathrm{a}$ & $14 \mathrm{ab}$ \\
\hline
\end{tabular}

${ }^{\mathrm{z}}$ Measured on whole plants (roots, leaves, and stems) at $128 \mathrm{~d}$ after transplanting.

${ }^{\mathrm{y}}$ Letters represent the component(s) of the medium $(\mathrm{S}=$ sphagnum moss, $\mathrm{C}=$ coconut coir, $\mathrm{B}=$ douglas fir bark) and the numbers represent the percent of each component (e.g., $\mathrm{S}_{30} \mathrm{C}_{30} \mathrm{~B}_{30}$ is $30 \%$ peatmoss, $30 \%$ coir, and $30 \%$ bark). Each non-commercial medium also contained $10 \%$ perlite (see Table 1 ).

${ }^{\mathrm{x}}$ Mixture model $P$ values, adjusted correlation coefficients $\left(r^{2}\right.$ adj), and coefficients $(\beta)$ for each model component. Coefficients followed by the same lower-case letter within a column are not significantly different based on Tukey's honestly significant difference test $(P \leq 0.05)$. *Significantly different from the commercial mix at a 95\% level using Dunnett-Hsu adjustment.

Table 6. Nutrient uptake efficiency by 'Snowchaser' blueberry plants grown in pots containing different media mixes.

\begin{tabular}{lcccccccccc}
\hline & \multicolumn{10}{c}{ Nutrient uptake efficiency $(\%)^{\mathrm{y}}$} \\
\cline { 2 - 10 } Medium $^{z}$ & $\mathrm{~N}$ & $\mathrm{P}$ & $\mathrm{K}$ & $\mathrm{S}$ & $\mathrm{Ca}$ & $\mathrm{Mg}$ & $\mathrm{Mn}$ & $\mathrm{B}$ & $\mathrm{Cu}$ & $\mathrm{Zn}$ \\
\hline $\mathrm{S}_{30} \mathrm{C}_{30} \mathrm{~B}_{30}$ & $58^{*}$ & 27 & $10^{*}$ & $3.6^{*}$ & $19^{*}$ & $33^{*}$ & 32 & 35 & $14^{*}$ & 6 \\
$\mathrm{~S}_{90}$ & $74^{*}$ & $41^{*}$ & $26^{*}$ & $5.2^{*}$ & 6 & $14^{*}$ & $79^{*}$ & 47 & $154^{*}$ & $16^{*}$ \\
$\mathrm{~S}_{60} \mathrm{~B}_{30}$ & $61^{*}$ & $33^{*}$ & 20 & $3.7^{*}$ & 5 & $10^{*}$ & 44 & 40 & 18 & 8 \\
$\mathrm{~S}_{60} \mathrm{C}_{30}$ & $67^{*}$ & $36^{*}$ & 15 & $4.0^{*}$ & $7^{*}$ & $10^{*}$ & $64^{*}$ & 39 & 125 & $14^{*}$ \\
$\mathrm{C}_{90}$ & $69^{*}$ & 24 & $10^{*}$ & $4.2^{*}$ & $11^{*}$ & $41^{*}$ & 46 & 32 & 129 & 11 \\
$\mathrm{C}_{60} \mathrm{~B}_{30}$ & $63^{*}$ & $38^{*}$ & $11^{*}$ & $3.7^{*}$ & 6 & $8^{*}$ & $53^{*}$ & 42 & $30^{*}$ & 12 \\
$\mathrm{C}_{60} \mathrm{~S}_{30}$ & $61^{*}$ & $30^{*}$ & $10^{*}$ & $3.6^{*}$ & $7^{*}$ & $11^{*}$ & $59^{*}$ & 31 & 122 & $13^{*}$ \\
$\mathrm{~B}_{90}$ & $21^{*}$ & 12 & $7^{*}$ & 1.3 & $1^{*}$ & $2^{*}$ & 24 & $14^{*}$ & $3^{*}$ & $3^{*}$ \\
$\mathrm{~B}_{60} \mathrm{C}_{30}$ & 35 & 22 & $8^{*}$ & 2.2 & $2^{*}$ & 4 & 27 & $22^{*}$ & $8^{*}$ & $4^{*}$ \\
$\mathrm{~B}_{60} \mathrm{~S}_{30}$ & 34 & 22 & $11^{*}$ & 2.2 & $2^{*}$ & 4 & 18 & $22^{*}$ & $5^{*}$ & $3^{*}$ \\
Commercial & 39 & 19 & 17 & 1.8 & 4 & 5 & 28 & 41 & 75 & 8
\end{tabular}

mix

Mixture model results ${ }^{\mathrm{x}}$

$P$ value $\quad<0.0001<0.0001<0.0001<0.0001<0.0001<0.0001<0.0001<0.0001<0.0001<0.0001$ $\begin{array}{lllllllllll}r^{2} \text { adj } & 0.5916 & 0.4663 & 0.6388 & 0.5712 & 0.5527 & 0.5466 & 0.5037 & 0.4737 & 0.8838 & 0.6698\end{array}$ Coefficients $(\beta)$

\begin{tabular}{|c|c|c|c|c|c|c|c|c|c|c|}
\hline Peat & $76 \mathrm{a}$ & $37 a$ & $22 \mathrm{a}$ & $5 a$ & $7 a$ & $13 \mathrm{~b}$ & $69 \mathrm{a}$ & $46 \mathrm{a}$ & $140 \mathrm{a}$ & $13 \mathrm{a}$ \\
\hline Coir & $67 \mathrm{a}$ & $21 \mathrm{~b}$ & $7 \mathrm{~b}$ & $4 \mathrm{a}$ & $11 \mathrm{a}$ & $25 \mathrm{a}$ & $52 \mathrm{a}$ & $37 \mathrm{a}$ & $146 \mathrm{a}$ & $14 \mathrm{a}$ \\
\hline Bark & $25 \mathrm{~b}$ & $15 \mathrm{~b}$ & $6 \mathrm{~b}$ & $1 \mathrm{~b}$ & $2 \mathrm{~b}$ & $3 c$ & $14 \mathrm{~b}$ & $17 \mathrm{~b}$ & $2 b$ & $2 \mathrm{~b}$ \\
\hline
\end{tabular}

${ }^{\mathrm{z}}$ Letters represent the component(s) of the medium $(\mathrm{S}=$ sphagnum moss, $\mathrm{C}=$ coconut coir, $\mathrm{B}=$ douglas fir bark) and the numbers represent the percent of each component (e.g., $\mathrm{S}_{30} \mathrm{C}_{30} \mathrm{~B}_{30}$ is $30 \%$ peatmoss, $30 \%$ coir, and 30\% bark). Each non-commercial medium also contained $10 \%$ perlite (see Table 1).

${ }^{\mathrm{y}}$ Percent of each nutrient supplied by fertilizers and the media mix at $128 \mathrm{~d}$ after transplanting.

${ }^{\mathrm{x}}$ Mixture model $P$ values, adjusted correlation coefficients $\left(r^{2}\right.$ adj $)$, and coefficients $(\beta)$ for each model component. Coefficients followed by the same lower-case letter within a column are not significantly different based on Tukey's honestly significant difference test $(P \leq 0.05)$. *Significantly different from the commercial mix at a $95 \%$ level using Dunnett-Hsu adjustment. 


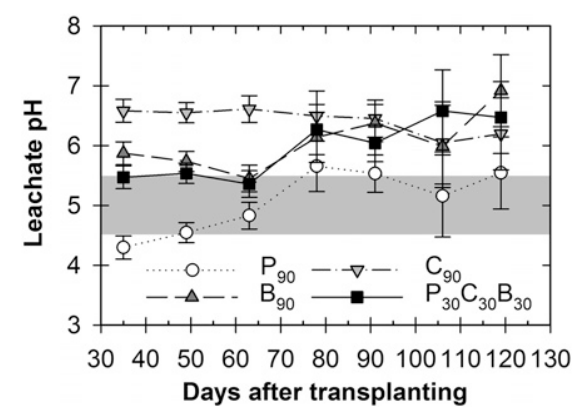

Fig. 2. Leachate $\mathrm{pH}$ from four media mixes used to grow 'Snowchaser' blueberry in pots for $128 \mathrm{~d}$. Each treatment contained $10 \%$ perlite, by volume, and $90 \%$ sphagnum moss $\left(\mathrm{S}_{90}\right), 90 \%$ coir $\left(\mathrm{C}_{90}\right), 90 \%$ douglas fir bark $\left(\mathrm{B}_{90}\right)$, or $30 \%$ each of peat, coir, and bark $\left(\mathrm{S}_{30} \mathrm{C}_{30} \mathrm{~B}_{30}\right)$. Symbols represent the mean of three replicates, and error bars represent the least significant difference $(P \leq 0.05)$. The gray shading represents the optimum soil $\mathrm{pH}$ range for highbush blueberry (Retamales and Hancock, 2012).

production of nursery plants (Bilderback et al., 2013). In soilless substrate, plants will experience drought stress at much higher tensions (less water depletion) than soilgrown plants $(-10$ and $-1500 \mathrm{kPa}$, in substrate and soil, respectively; Raviv et al., 2001).

de Boodt and Verdonck (1971) defined easily available water (EAW, the volume of water released between -1 and $-5 \mathrm{kPa}$ ) and water buffering capacity (WBC, the volume released between -5 and $-10 \mathrm{kPa}$ ) as two critical aspects of substrate water relations. Fields et al. (2014) measured EAW and WBC for peat, coir, and pine bark and found that the EAW of bark was $\approx 20 \%$ of that for peat and coir. Gabriel et al. (2009) observed a positive linear relationship of EAW with the addition of peat to douglas fir bark, which may explain why blueberry responded well to a 2:1 mix of peat and bark in the present study.

The effects of physical properties of media on water distribution may also play a role in growth and production of potted blueberry plants. Owen and Altland (2008) observed vertical stratification of water availability in containers of douglas fir bark, where it was as much as $50 \%$ lower in the top $2.5 \mathrm{~cm}$ of a $15-\mathrm{cm}$ tall container than in the bottom. Given that the root system of the plants was only $7-\mathrm{cm}$ long at transplanting in the present study, it is likely that the plants grown in media containing a high proportion of bark experienced periods of water stress between irrigations. A small decrease in available water will reduce stomatal conductance $\left(g_{\mathrm{S}}\right)$ (Améglio et al., 2000), cell expansion, and photosynthetic productivity in blueberry (Andersen et al., 1979; Cameron et al., 1988). Because all treatments were irrigated on the same schedule, media with high amounts of bark likely reached stressful tension levels and growth limiting conditions sooner than media with more peat or coir. In fact, when plants were grown in $90 \%$ bark,
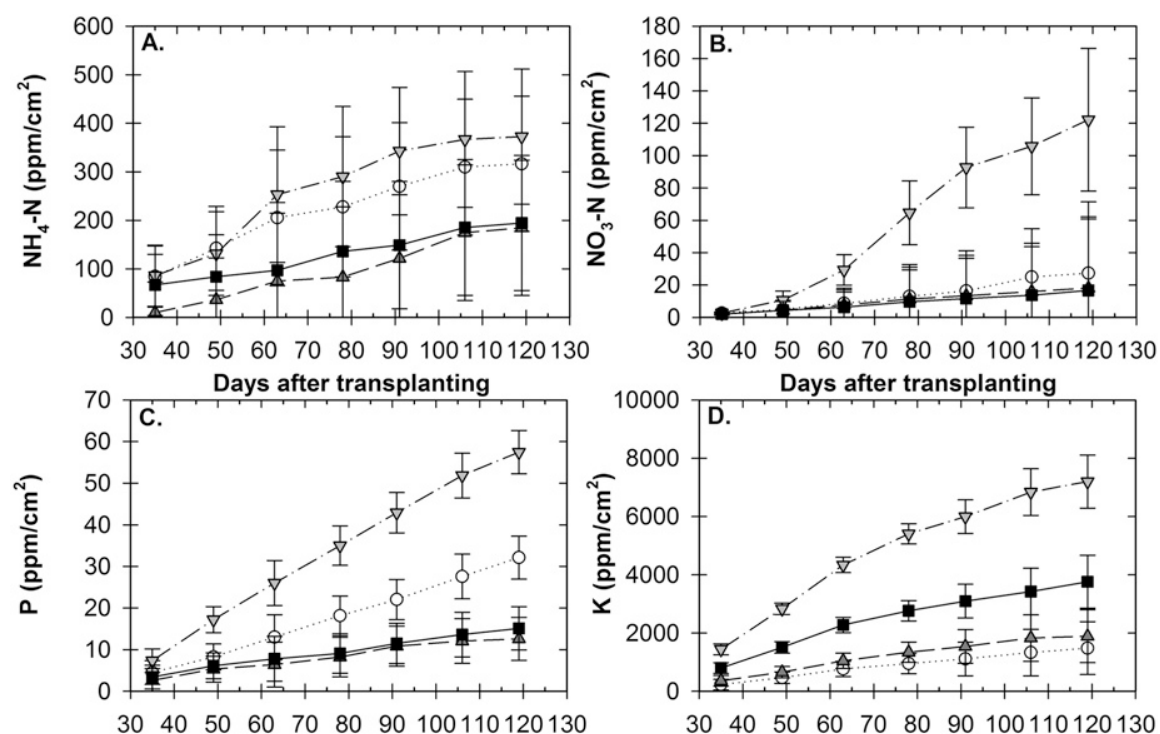

$30 \quad 40 \quad 50 \quad 60 \quad 70 \quad 8090100110120130$
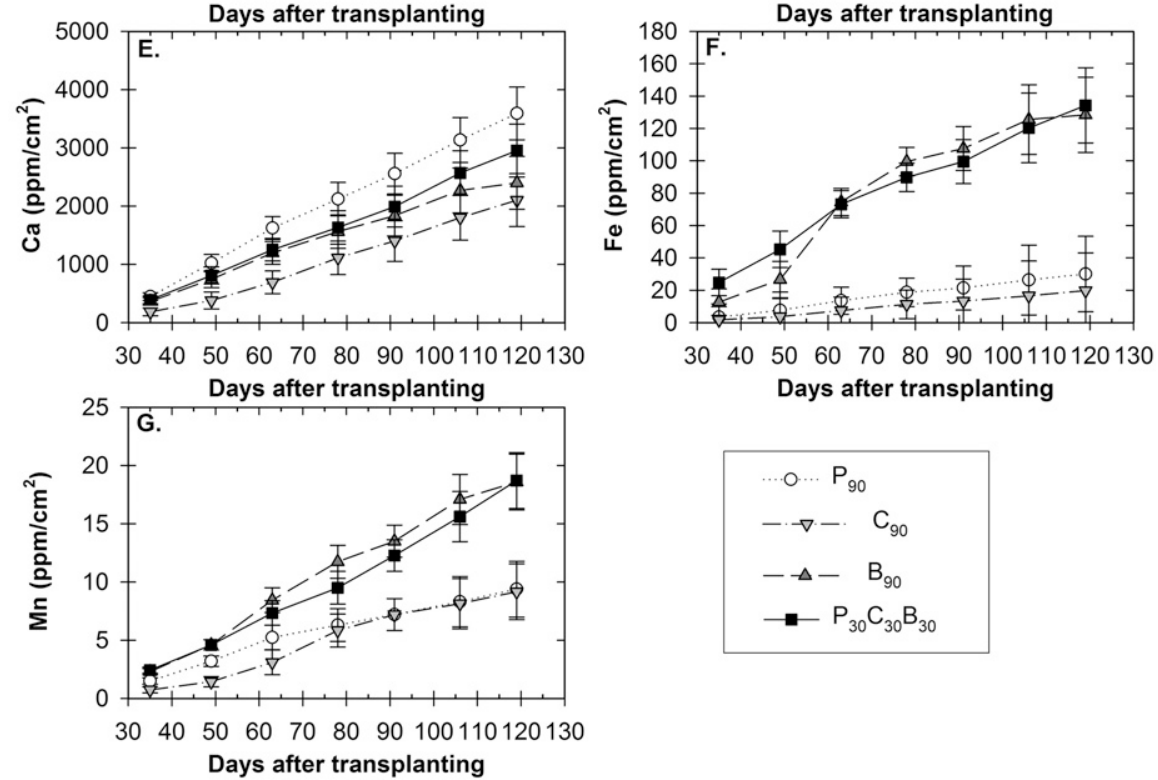

Days after transplanting

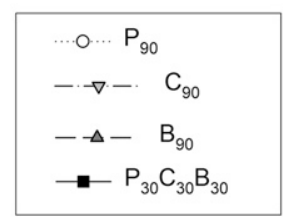

Fig. 3. Cumulative availability of $(\mathbf{A})$ ammonium-N $\left(\mathrm{NH}_{4}-\mathrm{N}\right),(\mathbf{B})$ nitrate- $\mathrm{N}\left(\mathrm{NO}_{3}-\mathrm{N}\right),(\mathbf{C}) \mathrm{P},(\mathbf{D}) \mathrm{K},(\mathbf{E}) \mathrm{Ca}$, (F) $\mathrm{Fe}$, and (G) $\mathrm{Mn}$ in four media mixes used to grow potted plants of 'Snowchaser' blueberry. The mixes contained $10 \%$ perlite, by volume, and $90 \%$ sphagnum moss $\left(\mathrm{S}_{90}\right), 90 \%$ coir $\left(\mathrm{C}_{90}\right), 90 \%$ douglas fir bark $\left(\mathrm{B}_{90}\right)$, or $30 \%$ each of peat, coir, and bark $\left(\mathrm{S}_{30} \mathrm{C}_{30} \mathrm{~B}_{30}\right)$. Symbol represents the mean of three replicates, and error bars represent the least significant difference $(P \leq 0.05)$.

altering fertigation from every other day to every day improved growth and reversed $\mathrm{N}$ deficiency symptoms observed shortly after planting. When commercial growers use media containing high amounts of bark, they tend to increase irrigation and give plants more fertilizer than when using media containing more peat (J. Umble, personal communication).

The influence of substrate moisture retention on nutrient availability can also affect plant response to media components. Dry substrate in the top of the container can lead to water channeling and quick drainage of solution (Hoskins et al., 2014). Higher cumulative drainage in douglas fir bark compared with peat and coir treatments confirmed a reduction in fertigation solution retention, which likely contributed to the reduced nutrient availability of $\mathrm{P}$ and $\mathrm{K}$ compared with peat and coir treatments. The reduced $\mathrm{N}$ uptake efficiency of $\mathrm{N}$ in douglas fir bark as compared with peat- and coirgrown plants, coupled with observations of $\mathrm{N}$ deficiency, higher $\mathrm{C}: \mathrm{N}$, and lower $\mathrm{NH}_{4}-\mathrm{N}$ availability, suggest that early $\mathrm{N}$ deficiency may also have contributed to reduced plant growth in bark.

Growth was similar when blueberry was grown in media with high proportions of peat and coir and was comparable in both cases to the commercial peat mix. However, there were a few notable differences in NUE between these substrates. Increasing peat improved the efficiency of $\mathrm{P}$ and $\mathrm{K}$ uptake relative to increasing coir in the media but reduced the efficiency of $\mathrm{Mg}$ and Fe uptake.

Differences in $\mathrm{Mg}$ and $\mathrm{Fe}$ uptake efficiency between peat and coir were related to relative differences content of the nutrients 
supplied by the media and not to their availability in the media or the plants ability to absorb these nutrients. Peat, for example, contained an order of magnitude more $\mathrm{Mg}$ and $\mathrm{Fe}$ than coir; however, peat- and coirgrown plants did not differ in DW, whole plant concentration of $\mathrm{Mg}$ and $\mathrm{Fe}$, or availability of $\mathrm{Mg}$ and $\mathrm{Fe}$ (as estimated by ionselective membrane probes) during the experiment. These results indicate the initial $\mathrm{Mg}$ and Fe nutrient content of the media (the denominator in the nutrient use efficiency calculation) was the driving factor for the observed differences in uptake efficiency between peat and coir for these nutrients. Others have also reported that $\mathrm{Mg}$ and $\mathrm{Fe}$ uptake was similar between media containing coir and peat (Scagel, 2003).

Differences in $\mathrm{K}$ uptake efficiency between peat and coir were related to relative differences in $\mathrm{K}$ content between the media and $\mathrm{K}$ availability during the experiment. Peat had greater $\mathrm{K}$ uptake efficiency than coir, but $\mathrm{K}$ availability in the media and plant tissue $\mathrm{K}$ concentrations were greater with coir. Uptake of $\mathrm{K}$ occurs through diffusion and is dependent on the concentration of $\mathrm{K}$ cations in solution that is in contact with the roots (Nieves-Cordones et al., 2014). The higher $\mathrm{K}$ concentration in coir-grown plants was not enough to offset the effects of the very high $\mathrm{K}$ concentration in the coir media on its nutrient use efficiency. Coir is known to contain high amounts of $\mathrm{K}$ and can increase $\mathrm{K}$ uptake (Evans et al., 1996; Scagel, 2003).

Differences in $\mathrm{P}$ uptake efficiency between peat and coir may be related to how these ingredients alter media $\mathrm{pH}$. Although coir contained more $\mathrm{P}$ than peat and had greater $\mathrm{P}$ availability during the experiment than peat, peat- and coir-grown plants did not differ in whole plant $\mathrm{P}$ concentration. Uptake of $\mathrm{P}$ is highly dependent on $\mathrm{pH}$, not only just for the availability of $\mathrm{P}$ in the root environment, but also the ability of plants to absorb $\mathrm{P}$ (Schachtman et al., 1998). Coir can contain more $\mathrm{P}$ than peat, and $\mathrm{P}$ uptake in coir-based mixes can be greater than that in peat when mixes containing peat and coir have similar pH (Evans et al., 1996; Scagel, 2003). In our experiment, lower leachate $\mathrm{pH}$ in peat than in coir may have contributed to greater $\mathrm{P}$ uptake efficiency in peat.

Interestingly, availability of $\mathrm{NO}_{3}-\mathrm{N}$ was elevated in the medium with $90 \%$ coir. Coircontaining media can contain greater levels of available $\mathrm{NH}_{4}-\mathrm{N}$ and $\mathrm{NO}_{3}-\mathrm{N}$ than similar peat-containing media and may result in greater $\mathrm{N}$ uptake when media has similar pH (Scagel, 2003; Stamps and Evans, 1999). Higher $\mathrm{pH}$ can increase the likelihood of nitrification and $\mathrm{N}$ losses (Havlin et al., 2014). In substrate production using coir, frequent fertigation that supplies $\mathrm{NH}_{4}-\mathrm{N}$ to plants might overcome $\mathrm{N}$ losses to nitrification at higher $\mathrm{pH}$. However, in our study, the concentration of $\mathrm{N}$ in the plants was lower in coir than in peat, which over time could become an issue. Blueberry prefers $\mathrm{NH}_{4}-\mathrm{N}$ to $\mathrm{NO}_{3}-\mathrm{N}$ (Retamales and Hancock, 2012), and these findings illustrate the importance of
$\mathrm{pH}$ management of substrate, particularly in long-term production to maintain $\mathrm{N}$ in the desired $\mathrm{NH}_{4}-\mathrm{N}$ form. More $\mathrm{N}$ fertilizer may be needed for longer term fruit production in coir, but further research is warranted.

Most of the differences in nutrient use efficiency in this study were the result of differences initial media concentrations. After $128 \mathrm{~d}$, it did not appear that blueberry plants grown in peat or coir required different fertilization as growth was similar between these ingredients. However, the multiyear duration of fruit production could lead to changes in media properties such as nutrient retention or porosity. Numerous studies have documented the change in substrate physical and chemical properties as a result of longterm plant growth and media decomposition (Jackson et al., 2009; Raviv, 2016). Future research on media selection for blueberry should also focus on changes in media properties over the long term and on maintaining equal or adequate moisture levels in the medium. Although blueberry generally starts producing fruit earlier in substrate than in the field, the plants must be grown in containers for at least several years for substrate-production to be considered economical (B. Strik, personal observation).

\section{Literature Cited}

Altland, J.E. and M.G. Buamscha. 2008. Nutrient availability from douglas fir bark in response to substrate $\mathrm{pH}$. HortScience 43:478-483.

Améglio, T., X. Le Roux, M. Mingeau, and C. Perrier. 2000. Water relations of highbush blueberry under drought conditions. Acta Hort. 537:273-278.

Andersen, P.C., D.W. Buchanan, and L.G. Albrigo. 1979. Water relations and yields of three rabbiteye blueberry cultivars with and without drip irrigation. J. Amer. Soc. Hort. Sci. 104:731-736.

Berruti, A. and V. Scariot. 2011. Coconut fiber: A peat-like substrate for acidophilic plant cultivation. Acta Hort. 952:629-635.

Bilderback, T.E., C.R. Boyer, M. Chappell, G.B Fain, D. Fare, C. Gilliam, B.E. Jackson, J. LeaCox, A.V. LeBude, A.X. Niemiera, J.S. Owen, J. Ruter, K. Tilt, S. Warren, S. White, T. Whitewell, R. Wright, and T. Yeager. 2013. Best management practices: Guide for producing nursery crops. 3rd ed. Southern Nursery Association, Acworth, GA.

Brazelton, C. 2016. World blueberry production summary and trends. Presentation at the 2016 SE Regional Fruit and Vegetable Conference and Tradeshow, 7-10 Jan. 2016. 6 July 2017. $<$ http://dev.manicmoosemedia.com/SERegional/ wp-content/uploads/4.-Cort-Brazelton-WorldBlueberry-Acreage-and-Production-2016.pdf $>$.

Buamscha, M.G., J.E. Altland, D.M. Sullivan, D.A. Horneck, and J. Cassidy. 2007. Chemical and physical properties of douglas fir bark relevant to the production of container plants. HortScience 42:1281-1286.

Cameron, J.S., C.A. Brun, and C.A. Hartley. 1988. The influence of soil moistsure stress on the growth and gas exchange characteristics of young highbush blueberry plants (Vaccinium corymbosum L.). Acta Hort. 241:254-259.

Cornell, J.A. 2011. Experiments with mixtures: Designs, models, and the analysis of mixture data. 3rd ed. Wiley, New York. de Boodt, M. and O. Verdonck. 1971. The physical properties of the substrates in horticulture. Acta Hort. 26:37-44.

Evans, M.R., S. Konduru, and R.H. Stamps. 1996. Source variation in physical and chemical properties of coconut coir dust. HortScience 31:965-967.

Fields, J.S., W.C. Fonteno, B.E. Jackson, J.L. Heitman, and J.S. Owen. 2014. Hydrophysical properties, moisture retention, and drainage profiles of wood and traditional components for greenhouse substrates. HortScience 49:827832.

Fulcher, A., N.W. Gauthier, W.E. Klingeman, F. Hale, and S.A. White. 2015. Blueberry culture and pest, disease, and abiotic disorder management during nursery production in the southeastern US: A review. J. Environ. Hort. 33:33-47.

Gabriel, M.Z., J.E. Altland, and J.S. Owen. 2009. The effect of physical and hydraulic properties of peatmoss and pumice on douglas fir bark based soilless substrates. HortScience 44:874878.

Gavlak, R.G., D.A. Horneck, and R.O. Miller. 2003. Plant, soil, and water reference methods for the western region. Western Region Extension Publication WREP-25. Corvallis, OR.

Hammond, R.F. 1975. Origin, formation and distribution of peatland resources. In: D.W. Robinson and J.G.D. Lamb (eds.). Peat in horticulture. Academic Press, London, UK.

Hart, J., B.C. Strik, and H. Rempel. 2006a. Caneberries. Nutrient management guide. Oregon State Univ. Ext. Serv., EM8903-E. 6 July 2017. $<$ http://ir.library.oregonstate.edu/xmlui/bitstream/handle/1957/20427/em8903-e.pdf>.

Hart, J.M., B.C. Strik, L. White, and W. Yang. 2006b. Nutrient management for blueberries in Oregon. Ore. St. Univ. Ext. Serv. Publ. EM 8918. Ore. St. Univ., Corvallis, OR. 6 July 2017. <http://ir.library.oregonstate.edu/xmlui/ bitstream/handle/1957/20444/em8918.pdf>.

Havlin, J.L., J.D. Beaton, S.L. Tisdale, and W.L. Nelson. 2014. Soil fertility and fertilizers: An introduction to nutrient management. 8th ed. Prentice Hall, Upper Saddle River, NJ.

Hoagland, D.R. and D.I. Arnon. 1938. The waterculture method for growing plants without soil. University of California, College of Agriculture, Agricultural Experiment Station, Berkeley, CA. Circular 347:1-39.

Hoskins, T.C., J.S. Owen, and A.X. Niemiera. 2014. Water movement through a pine-bark substrate during irrigation. HortScience 49: 1432-1436.

Jackson, B.E., R.D. Wright, and J.R. Seiler. 2009. Changes in chemical and physical properties of pine tree substrate and pine bark during longterm nursery crop production. HortScience 44:791-799.

Jones, J.B. and V.W. Case. 1990. Sampling, handling, and analyzing plant tissue samples, $\mathrm{p}$. 389-427. In: R.L. Westerman (ed.). Soil testing and plant analysis. 3rd ed. Soil Sci. Soc. Amer., Madison, WI.

Knight, P.R., J.M. Anderson, and R.A. Parks. 1998. Impact of coir-based media in azalea growth. Proc. Southern Nursery Assn. Res. Conf. 43:28-31.

Korcak, R.F. 1988. Nutrition of blueberry and other calcifuges. Hort. Rev. 10:183-227.

Lenth, R.V. 2016. Least-squares means: The R package lsmeans. J. Stat. Softw. 69:1-33.

Machado, R.M.A., D.R. Bryla, and O. Vargas. 2014. Effects of salinity induced by ammonium sulfate fertilizer on root and shoot growth of highbush blueberry. Acta Hort. 1017:407-414. 
Niedziela, C.E. and P.V. Nelson. 1992. A rapid method for determining physical properties of undisturbed substrate. HortScience 27:12791280.

Nieves-Cordones, M., F. Alemán, V. Martínez, and F. Rubio. 2014. K+ uptake in plant roots. The systems involved, their regulation and parallels in other organisms. J. Plant Physiol. 171:688-695.

Owen, J.S. and J.E. Altland. 2008. Container height and douglas fir bark texture affect substrate physical properties. HortScience 43:505-508.

Pinheiro, J., D. Bates, S. DebRoy, and D. Sarkar. R Core Team. 2016. nlme: Linear and nonlinear mixed effects models. R package version 3 .

R Core Team. 2016. R: A language and environment for statistical computing. R Foundation for Statistical Computing, Vienna, Austria. 6 July 2017. <https://www.R-project.org/>.

Raviv, M. 2016. Substrate's end-of-life: Environmental and horticultural considerations. Acta Hort. 1112:281-290.

Raviv, M., J.H. Lieth, D.W. Burger, and R. Wallach. 2001. Optimization of transpiration and potential growth rates of 'Kardinal' rose with respect to root-zone physical properties. J. Amer. Soc. Hort. Sci. 126:638-643.

Retamales, J.B. and J.F. Hancock. 2012. Blueberries. Crop production science in horticulture series. CABI International, Wallingford, UK.

Righetti, T., K. Wilder, R. Stebbins, D. Burkhart, and J. Hart. 1998. Apples: Nutrient management guide. Ore. St. Univ. Ext. Serv. EM8712.

Robbins, C. and C.L. Wiegand. 1990. Field and laboratory measurements, p. 76-78. In: K.K Tanji (ed.). Standard methods for the examination of waste water. Agricultural Salinity Assessment and Management. Amer. Soc. Civil Engineers, New York, NY.

Scagel, C.F. 2003. Growth and nutrient use of ericaceous plants grown in media amended with sphagnum moss peat or coir dust. HortScience 38:46-54.

Scagel, C.F., G. Bi, L.H. Fuchigami, and R.P. Regan. 2007. Seasonal variation in growth, nitrogen uptake and allocation by container-grown
Rhododendron cultivars. HortScience 42:1440 1449.

Schachtman, D.P., R.J. Reid, and S.M. Ayling. 1998. Phosphorus uptake by plants: From soil to cell. Plant Physiol. 116:447-453.

Scheffé, H. 1958. Experiments with mixtures. J. Royal Stat. Soc. Ser. B (Methodological) 20:344-360.

Sims, G.K., T.R. Ellsworth, and R.L. Mulvaney. 1995. Microscale determination of inorganice nitrogen in water and soil extracts. Commun. Soil Sci. Plant Analysis 26:303-316.

Stamps, R.H. and M.R. Evans. 1999. Growth of Dracaena marginata and Spathiphyllum 'Petite' in Sphagnum peat- and coconut coir dust-based growing media. J. Environ. Hort. 17:49-52.

Voogt, W., P. van Dijk, F. Douven, and R. van der Maas. 2014. Development of a soilless growing system for blueberries (Vaccinium corymbosum): Nutrient demand and nutrient solution. Acta Hort. 1017:215-221.

Wright, R.D. 1986. The pour-through nutrient extraction procedure. HortScience 21:227. 